\title{
CONTEMPORARY TRENDS IN OUTSOURCING OF ACCOUNTING AND FINANCIAL SERVICES
}

\author{
Ivana Tomašević ${ }^{1}$ \\ Adriatic University, Faculty of Business Economics - Bar, Montenegro
}

\begin{abstract}
Existing researches on business indicates that companies in order to survive on the modern market must: constantly develop their own capacities, make constant effort to reduce costs and to optimize the use of their own resources. Shortcomings in knowledge and skills, key competencies, and resources are highlighted as main causes of company decay. One way to overcome existing shortcomings is to get into the outsourcing process. Outsourcing can be applied to basic business functions, specialized business functions and business support functions. The subject of this paper is to present the factors that influence the outsourcing of accounting services as well as contemporary trends in the field of accounting and financial services outsourcing. The paper presents theoretical considerations on the topic, the specifics of the accounting services that are to be taken into account when making the decision about entering into outsourcing process, as well as the trends in the outsourcing business.
\end{abstract}

Key words: accounting, accounting services outsourcing, transaction costs economics, resource based view, trends in accounting outsourcing

\section{INTRODUCTION}

In order to develop and survive in the modern market, in accordance with the Theory of Resource Optimization companies have to reduce costs and to optimize the use of their own resources (Plenert, 1993, p.132). In other words, with the optimal utilization of the company's own resources companies can achieve a competitive advantage.

Research on this topic shows that the root causes of enterprise decay are: lack of planning, lack of knowledge and skills, lack of management skills and lack of key competences (Dyer \& Ros, 2008, p.135). The question that we need to answer is: how companies can overcome shortcomings in resources, knowledge and skills?

One approach is to rely on outsourcing. With reliance on outsourcing, which means engaging external service providers, companies can come up with some knowledge and skills that they are lacking.

From entering the outsourcing process, especially micro, small and medium enterprises are getting the opportunity to improve their own capacities through:

1. Cost reduction and

2. Better utilization of resources

${ }_{1}$ i.tomasevic@bscbar.org

Vol. 20, бpoj 2/2018, cmp. 17-33 
However, outsourcing is not always related only to small and medium sized companies, often large companies enter into outsourcing process. Their reason for entering this process is to: get the missing specialized skills, reduce costs and improve competitiveness on global market and similar. In recent years, outsourcing has developed significantly in all areas, so there are situations in which companies use outsourcing and as their strategic direction that enables them to specialize, grow and to develop (McIvor, 2009, p.46).

In researching outsourcing most studies are focusing on:

1. Production outsourcing (backward integration) or

2. Outsourcing marketing and distribution (forward integration) (Soberman \& Gatigon 2005, p.170).

A smaller number of studies is dedicated to outsourcing of support services such as: finance and accounting services.

Outsourcing of financial and accounting services has certain specificities in the outsourcing process and in relations between the actors. This paper presents the main factors that influence the decision on outsourcing, theoretical considerations, as well as the the results coming from the research that was carried out in the topic of outsourcing in accounting conducted in Montenegro.

\section{FACTORS THAT INFLUENCE OUTSORSING OF ACCOUNTING SERVICES}

Efficient financial management of the company is the key to the company's success. In order for the management to make effective decisions the information that they receive from the accounting on which those decisions are based must be accurate. Accounting information is important for making decisions, and therefore the company must properly organize the accounting process.

The most common problems linked to accounting for the company are (Kamyabi \& Devi, 2011, p. 90):

1. Lack of expertise and resources (Evaraert, Sarens \& Rommel, 2006; Marriott \& Marriott, 2000; Dibbern \& Heinzl, 2001; Ismail, 2002). 2002).

2. Lack of accounting knowledge and accounting support (Ismail,

3. Lack of accurate and adequate accounting data used as inputs in the decision-making process

The emergence of outsourcing as a practice has also contributed to the development of the company's success because it enabled them to provide (through outsourcing) the missing resources, knowledge and 
competencies in the field of accounting. In the last period, accounting outsourcing has developed so much that now we have a situation where companies are strategically opting for outsourcing accounting and especially when operating on the international market. Their decision is not affected so much by the lack of resources like lack of knowledge and competencies in accounting field, as it is affected by the fact that outsourcing a professional and experienced agency significantly reduces their own costs of acquiring accounting knowledge and experience.

Factors that influence the outsourcing of accounting in literature can generally be classified into the following groups (Jayabalan, Raman \& Kaliannan, 2009, p.98):

\section{Cost factor}

One of the most commonly investigated factors when discussing outsourcing is the cost. Companies can reduce costs through economy of scale by outsourcing accounting functions to an external accountant (Everaert, Sarens \& Rommel, 2006; Kakabadse \& Kakabadse, 2002), in such a way that the external service provider will pay only the costs of the specific work. In other words, the fixed costs (hiring additional workers for a larger workload, additional administrative expenses) will turn into variable ones. Such arrangements greatly enhance flexibility and facilitate management (Burkholder, 2006, p.80).

In the empirical research carried out, it has been proven that enterprises managed to reduce costs by as much as $20 \%$ without reducing the quality of the service itself (Sedon, Cullen, \& Wilcocks, 2002)

\section{Resource factor}

The outsourcing process also depends on resources. Some companies have better infrastructure and accumulated experience and that is why it is a better option for the company to outsource services from them, than to invest in developing its own resources. In this way, company through outsourcing releases a part of its own resources and can use them for alternative purpose making the usage of resources are more efficient (Ya Ni \& Bretschneider, 2007).

\section{Competence factor}

Rikardo (1817) suggests that firms need to focus on an area in which they can gain a competitive advantage and outsource other relevant activities to other companies (subcontractors) that have different relative comparative advantages. Expertise required to perform a particular function often has a high impact on the decision to outsource this function. For example. For the field of accounting it is very important not only to know the basic principles but also to have the knowledge and experience on how to apply these principles to a specific enterprise in carrying out concrete task. That's why accounting outsourcing gains 
importance. With the development of technology and internet communications as well as social networks companies are often in situation that they don't have adequate inside resources to efficiently exploit new possibilities. In that case companies need to apply corrective measures to more efficiently exploit new possibilities. Primarily those measures relate to additionally engage specialized companies, agencies or consulting firms that have knowledge and experience in the intricacies or in certain segments. If organizations for certain reasons nevertheless decide not to hire an external specialized company, in that case it is almost necessary to select a specific person or to form a specific team that would be in charge, but also responsible for making decisions. In the concrete case, in addition to the aforementioned activities, it is necessary to additionally train staff and again for part of activities engage experts from the field. (Ilić \& Marković, 2016 p.55) In this case, sometimes when we look at the competences outsourcing might be the only option.

\section{Operational management factor}

Companies can achieve a comparative advantage by focusing their business on key activities such as, for example, production or sale and transfer support activities (i.e., which are not key activities) to other providers (Burkholder, 2006, p.82). In key activities, the company will improve its business through more efficient management, better dedication and better decision-making. It will also internally improve control and reduce administrative costs (Domberger, et. al., 2000, p. 110).

\section{Risk factor}

Risks involved in the outsourcing of accounting functions are, in any case, related to the public disclosure of various accounting information. Before the outsourcing decision is taken, decision makers are aware of the various risks that can arise. The risks are the following (Bragg, 2006):

- Changes in the supplier's business - e.g. the financial difficulties of the provider of accounting service can affect the efficiency of its performance.

- Failure of the service provider - e.g. If the provider does not deliver the report on time due to its own failure, the company will not have the information necessary for making important decisions.

- Loss of confidential information

In any case, if there is a high risk for accounting outsourcing, management will not outsource this function.

\section{Company size}

Opinions about the influence of the size of the company on the decision of outsourcing accounting are divided because more and more companies in the world use outsourcing as a strategic decision and 
especially when operating on an international market where procedures and regulations are different in different countries - spending resources on developing their own capacity in the field of accounting it is not practical. However, numerous studies on this topic prove that the size of the company has an impact on the decision of outsourcing the basic accounting functions, since smaller firms have fewer capacities, and so often because of costs, they opt for outsourcing to an external provider (Domberger, et. al., 2000, p. 112). This is especially important for micro companies that do not have their own capacity and need to outsource accounting. Very often, micro companies are excluded from an outsourcing accounting surveys to control the impact of company size on outsourcing (Everaert, et al., 2010, p.95 ).

Resource Based View (RBV) and Transaction cost ecomics (TCE) are most commonly used for the analysis of the factors that influence the outsourcing of the literature.

\section{ANALYSIS OF THE FACTORS SUPPORTING THE DECISION OF OUTSORSING ACCOUNTING- RESOURCE MODEL}

A resource-based approach or RBV is typical of small and medium-sized enterprises that base their decision on outsourcing based on resource constraints. A resource approach was developed in 1959 by Penrose, who provided a comprehensive explanation of the relationship between the company's resources and the company's performance. In other words, resource choices leading to optimal growth will have a direct impact on economic rents (profits): "There is a close relationship between the various resources the company has at its disposal and the development of ideas, experiences and knowledge by managers and entrepreneurs in the firm; and we can clearly see that changes in experience and knowledge affect not only productive services that are available from the resources themselves, but also on demand from the perspective of the company's observation. Unused productive services represent a challenge for innovation, an incentive for growth and a source of comparative advantage. These services make it easier to introduce new combinations of resource-innovation-within the company. (Penrose, 1959)

The RBV method was significantly developed in the 1980s and 1990s in works published by Wernerfelt (1984), Prahalad and Hamel (2006) and Barney. (1991). The essence of the approach is reflected in their view towards the achievement of a comparative advantage - with the companies turning to internal resources for achieving the benefits through the RBV method.

All companies have both physical and human resources associated

Vol. 20, бpoj 2/2018, cmp. 17-33 
with its organizational structure. Due to its touchable nature, physical property is easily identified (equipment, construction objects, etc.), while on the other hand intellectual property is a set of all untouchable aspects of human resources such as knowledge of employees, skills and their individual competence.

\section{Scheme 1: RBV approach for outsourcing strategy}

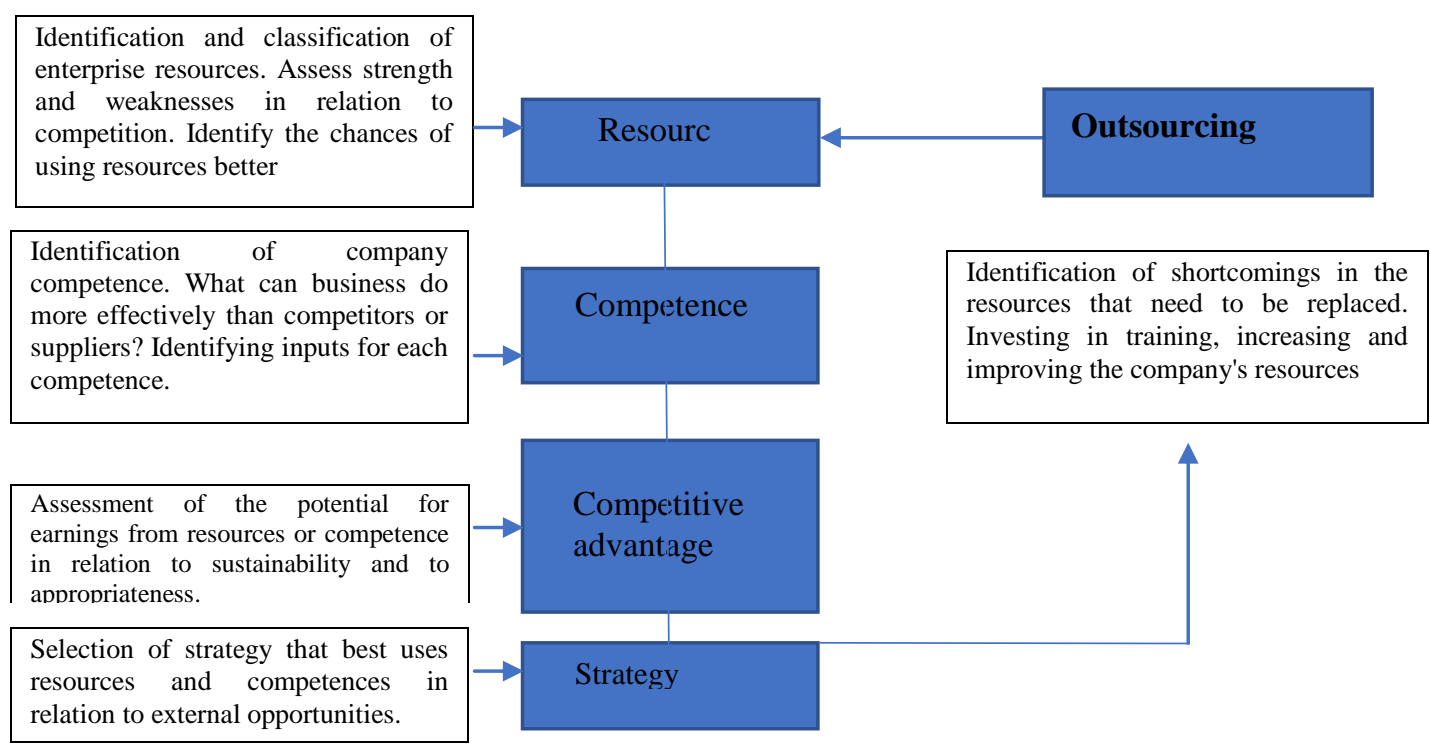

Source: Espino-Rodríguez \& Padrón-Robaina, V., 2006.

Basically RBV addresses two key conclusions:

1. That resources should have economic value, must be limited, rare, difficult to copy or imitate, unsustainable and inaccessible on the market of production factors in order to create a comparative advantage (McIvor, 2009, p.49).

2. Resources determine the performance in the business of the firm (McIvor, 2009, p.49) in the context of accounting; in this context resources mainly relates to knowledge, skills and competences of the company (Jayabalan, et al, 2009, p.110). For example. explicit knowledge of the accounting function is the knowledge of generally accepted principles and rules. However, applying these rules in a business environment requires practical and tacit knowledge. (Everaert, et al., 2010, p.90). Professional accountants gain tangible knowledge through practice, making this knowledge impossible to transfer. Small and medium enterprises have a lack of quality staff or knowledge to meet accounting requirements and organize all accounting functions. 
Therefore, RBV explains that SMEs use professional accounting services to support their business and advisory services (those gained through experience) in order to supplement their own resources shortcomings (Kamyabi \& Devi, 2011, p. 95).

Numerous studies of small and medium-sized enterprises use RBV in the analysis of factors that influence the outsourcing. Competition and strategy that a limited resource company has formed to respond to competitive pressures play an important role in the outsourcing decision. RBV focuses on developing skills and competencies in order to respond to competition and in order to achieve competitive advantage in the market (Barney, 1991; Gottschalk \& Solli-Sœther, 2006; Mclvor, 2009; Kamyabi \& Devi, 2011, p. 90), due to that competition becomes the basic factor influencing the decision to outsource accounting (Gooderham et al., 2004; Kamyabi \& Devi, 2011, p 95).

Unlike the RBV theory that the decision on outsourcing is based on the effects of external factors (competitive pressures), there is also a theory of transaction cost economics that primarily relies on internal factors, i.e., on management (Mclvor, 2009). From the above, we can conclude that these two theories are complementary, however, RBV is more appropriate for the analysis of small and medium-sized enterprises (especially micro-enterprises) because, due to the size and flexibility to adopt to market needs, external factors have a significant impact. The TCE includes external factors, but in a much more detailed way includes management and internal factors as arguments for the outsourcing decision. In the next section, we will look at the theory of transaction costs.

\section{ANALYSIS OF THE FACTORS SUPPORTING THE DECISION OF OUTSORSING ACCOUNTING- TRANSACTION COSTS ECONOMICS (TCE)}

The transaction cost economics (TCE) in the literature is used for the analysis of various types of outsourcing, e.g. in production (Walker \& Weber 1984 p. 375).

In economic theory, transaction costs are all costs that businesses must bear in order to carry out an economic transaction. There are many different transaction costs, for example, costs of searching and obtaining information on the market; cost estimation alternatives; research costs whether a particular product is available on the market, who has the best price, etc.

As mentioned above, there are 2 types of costs for businesses transaction costs and production costs. Transaction costs in this sense are 
"all costs that an enterprise must bear to process the information necessary to coordinate all human and capital resources involved in the production or delivery of a service."

The term transaction costs for the first time in the literature was used by R.H. Coase (1970), a British economist who used it to develop a theoretical model for predicting when certain economic tasks are more convenient to be performed within an enterprise and when it is better to perform them on the market. In his earlier work, this term appears earlier as "costs of market transactions".

The use of transaction costs in economic theory has been greatly enhanced by the American economist and winner of the Nobel Prize in Economics (2009) O.E. Williamson, who is considered to be the creator of the Transaction Cost Economics.

Transaction Cost Economics suggests that the costs and difficulties associated with market transactions sometimes favor the internal establishment of services (internal services or production), and sometimes outsourcing (the provision of services or products on the market under market conditions). Between these two extremes there are also other forms, for example, when a part of the services (or production) is performed within the company and part is supplied from other companies on the free market.

Based on the stated theory the decision whether certain tasks are performed within the company or whether the company will outsource them depends on the amount of transaction costs of both alternatives.

TCE represents a good framework for analyzing why individual companies prefer to organize accounting within a company, while other companies prefer engaging external accountants for the same type of service and thus reduce transaction costs. (Kamiabi \& Devi, 2011; Everaert, 2010; Klein, 2005). Costs of outsourcing accounting transactions must include all transaction costs that are: cost of contracting and of preparing contract with an accounting agency (ex-ante costs) as well as the cost of monitoring and providing feedback (ex-post costs) (Williamson 1985).

In accordance with the above, we can conclude that outsourcing accounting is preferable in situations where there is open market, i.e., when there is an open market game in which we have many potential suppliers (accounting agencies). Market mechanisms of open market minimize the need to monitor the quality of the service, i.e., supplier behavior (Hennart, 1989, p.211).

In cases where we do not have an open market, the number of providers of accounting services is small and they can behave opportunistically (i.e., the quality of accounting services provided by 
them is reduced). In order to reduce their opportunism, their work must be further monitored and checked, strengthened by a contractual relationship, which automatically increases transaction costs (Dwyer \& Oh, 1988). In such situations, the company will significantly reduce transaction costs by replacing external agencies that perform accounting services (suppliers) with their own employees because their behavior can be more effectively monitored, controlled, the quality monitoring business performance through accounting will be improved through reduced possibilities for error. The specific situation is when there are no adequate knowledge or quality staff in the company (Kamyabi \& Devi, 2011, p. 92) for carrying out certain accounting tasks; then companies are forced to acquire them from professional accountancy agencies because that is the only way to improve their own resources (Kamyabi \& Devi, 2011, p. 94). In this situation, the transaction costs of outsourcing are lower than the transaction costs of in-house development.

TCE assumes that the specificity of the assets and certainty i.e. the uncertainty that exists on the market are the two basic components that will affect the decision on outsourcing (Everaert et al., 2010, p.95; Lammirmiaki, 2005; Spekle et al., 2007).

Figure 2.: Components that affect transaction costs

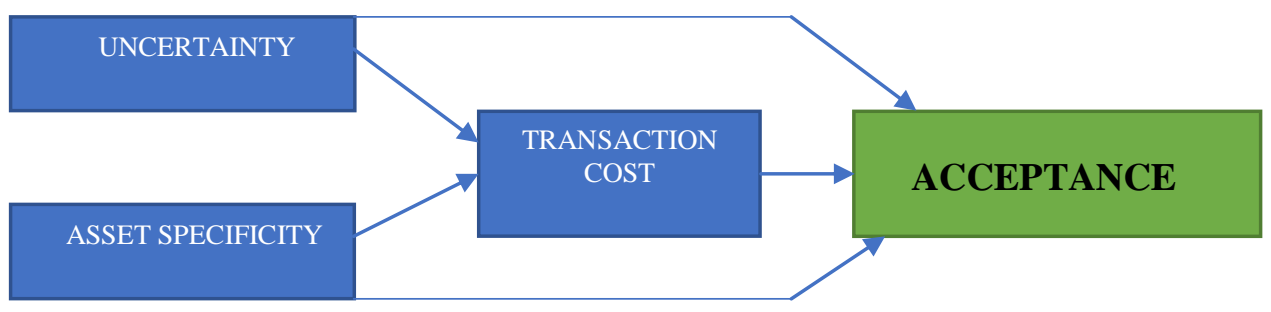

Source: Liang, J.- Hunag S.- decision support systems 24 (1998) 29-43

Apart from the above two components, it is also necessary to observe the trust in the external accountant and the frequency of services, because for some routine services that need to be performed frequently it is more likely to be able to reduce costs due to outsourcing (Everaert et al., 2010, p.95).

\section{TRENDS IN OUTSORCING}

Today, outsourcing involves the creation of strategic partnerships. Earlier, for example, it was not possible to imagine that some corporation accepts to outsource key competencies - functions that give that 
corporation strategic advantage or uniqueness on the market. One of the most important functions in the company is, for example, relationship with clients because this function deals with direct contact with customers - and precisely because it is so important this function is very much outsourced today.

Baumont and Khan (2005) define several forms or types of outsourcing today:

- Out-Tasking - The outsourcing user takes over services or tasks that are precisely defined by the company as a client;

- Insourcing - Formalizing a supplier relationship between two sections within an organization;

- Back sourcing or repatriation - Restoring a job that was once officially outsourced, to be done internally;

- Co-Sourcing - an outsourcing arrangement based on co-operation between different parties (partners in relationship);

- Strategic outsourcing - Outsourcing in a strategic context, i.e. when the company is opting for outsourcing as a strategy;

- Offshoring - When the work that is outsourced is done in another, foreign country;

- Business process outsourcing - Delegating business processes to an external provider.

As we see, in many languages, there are no suitable terms for the new forms of outsourcing and there is necessity to use English words.

Third generation of outsourcing goes far beyond the outsourcing of production and services or information technology outsourcing; Outsourcing is now growing in the field of professional services such as: legal, accounting, financial services.

The modern business arena is characterized by the great turbulence and complexity of the environment, due to the development of technology, technology and information systems. The changed environment has led to a dilemma where to produce - the constant advancement of technological capabilities and global communications, and the ever-expanding standardization of jobs provide conditions for creating even more favorable circumstances for offshore service (Stevanović \& Đurđević, 2017, p.83)

Muller and Wood (Strambach, 2008, p.152) recognize three basic types of outsourcing that are:

1. Outsourcing of basic (key) business functions - In this case what gets outsourced are key business activities and this outsourcing is characteristic for companies that have high intellectual capital, such as accounting and law firms. The decision on the outsourcing of these functions happens very rarely and when it happens outsourcing is based 
on a partnership relationship; contract between partners is created that specifies exactly that the company retains control of its key resourcestheir intellectual base. Of all types of outsourcing, this one is least used because businesses still refrain from outsourcing their key business function (but sometimes it is the only solution for growing).

2. Outsourcing of specialized business functions that are not part of the company's basic function - these are special services that cannot be found internally, but are not the main activities of the company. Examples include information technology services or human resources management. The decision to outsource these activities is mainly based on the lack of adequate resources within the firm.

3. Outsourcing the support functions - those functions are described as non-essential functions that are often helpful for the main activities of the company and that contribute to the realization of main functions. The decision to outsource these activities is mainly based on cost factors. Namely, if the cost of outsourcing is lower than the costs of organizing the support activities internally, the company will decide on outsourcing. Autsorsing support function can also be considered as the first generation of outsourcing.

Today, services at the market are largely outsourced. Namely, companies are increasingly involved in such relationships, while the market of outsorsing of specialized services and of support functions is growing more and more.

From the table in Figure 3, we can see that the market for service outsourcing in 2014 amounted to as much as 104.6 billion dollars, then it reached the highest level (the cause for that was the large application of information technoglogies in the company's operations). According to figures in 2017, the size of the outsourcing market was 88.9 billion euros.

Figure 3.: Outsoarcing market size in service outsorsing from 2000 to 2017 in billion of dollars

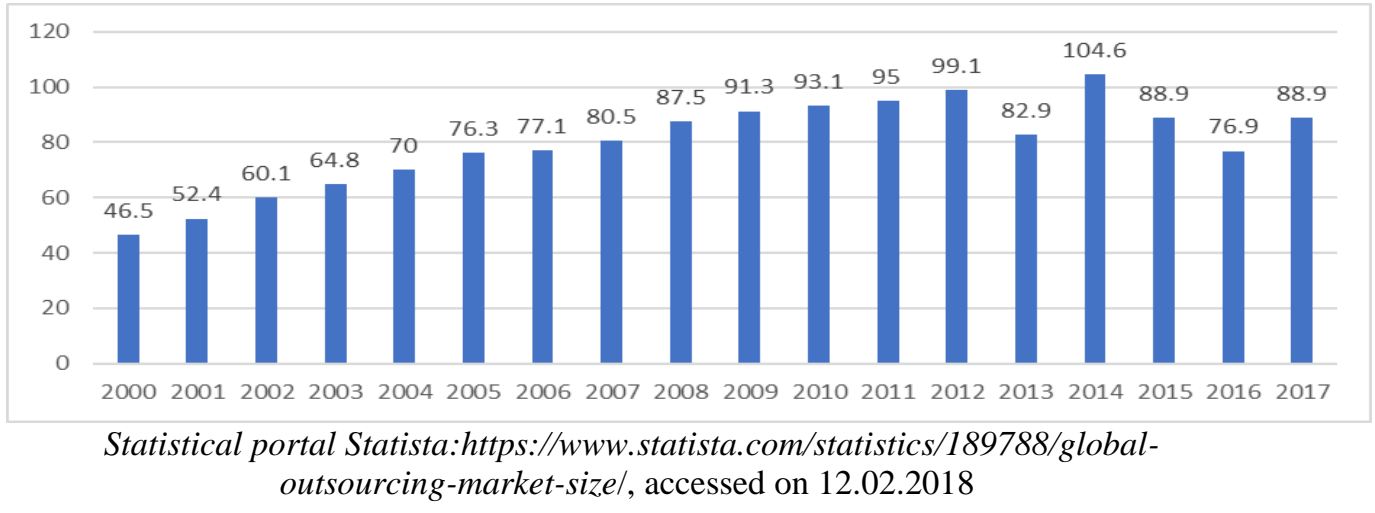

Vol. 20, бpoj 2/2018, cmp. 17-33 
In the following table, we see that outsourcing in the field of specialized services is still the highest form of outsorsing - to be precise information technology outsoarcing.

Figure 5.: Total revenue from outsourcing of services based in the type of service (information technology outsourcing or outsourcing of business processes) in percent

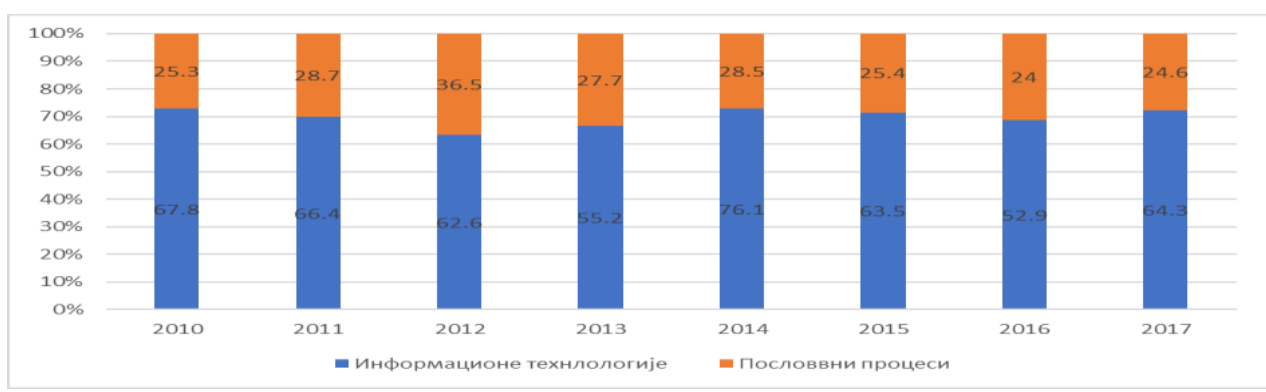

Statistical portal Statista: https://www.statista.com/statistics/189800/globaloutsourcing-industry-revenue-by-service-type/ accessed on 12.02.2018

\section{CONCLUSION}

Outsourcing of accounting services has been researched in many countries and research provided various information that improved the understanding of this area and contributed to identifying the specifics of accounting outsourcing.

Furthermore, research conducted by Stroyhal, Bonaci, Deacony, Myller and Pasekova, 2010 pointed to the need for users of accounting reports of small and medium-sized enterprises to implement and improve accounting regulations. The response to these problems was the creation of International Accounting Standards for Small and Medium Enterprises (Lindberg, \& Seifert, 2010, p.29), which significantly reduced disclosure requirements and financial and organizational burden on SMEs that existed as result from the SME's reporting needs.

On the one hand, the companies through outsourcing of accounting services have improved their own capacities and compensated for the scarce resources, while on the other hand, many companies engaged in the provision of accounting services acquired a lot of knowledge and experience not only in the field of basic accounting tasks and procedures, but also in: knowledge management, human resources, cash management, client management, budget - knowledge that can later be offered to other companies on the market for adequate compensation. Through outsourcing relationship, the market for professional accounting services has developed. 
A number of research on the outsourcing of the accounting function has been conducted, however, the research on this topic, for the countries that access to the European Union are still lacking. It is important to research this as in this environment there are additional factors that influence the decision on outsourcing like: introduction and compliance with the international accounting standards (accounting legislative changes), market uncertainty, quality of external accounting agency, and still underdeveloped capacities of the company for the application of international financial reporting standards.

Significant scientific contribution would come also from research of the influence of global trends (like social networks) and the way in which the development of modern technologies influenced the outsourcing of accounting, because there is also a trend of growth of outsourcing of accounting services.

\section{LITERATURE}

1. Awino, Z. B., \& Mutua, J. M. (2014). Business process outsourcing strategy and performance of Kenyan state corporations. Journal of emerging trends in economics and management sciences, 5(7), 37-43.

2. Barney, J. (1991). Firm resources and sustained competitive advantage. Journal of management, 17(1), 99-120.

3. Beaumont, N., \& Khan, Z. (2005). A taxonomy of refereed outsourcing literature. Melbourne/Australia: Monash University, Department of Management

4. Bengtsson, M., Eriksson, J., Wincent, J. (2010). Coopetition: new ideas for a new paradigm. In: Yami, S., Castaldo, S., Dagnino, G.B., Le Roy, F. (Eds.). Coopetition: Winning Strategies for the 21st Century. Edward Elgar, Northampton, MA, pp. 19-39.

5. Bengtsson, M., Kock, S. (2000). Coopetition" in business networks - to cooperate and compete simultaneously. Industrial Marketing Management, 29(5), 411-426.

6. Bhamra, R. (2012). Sustainable outsourcing: a practice survey and research opportunities. International Journal of Sustainable Engineering, 5(4), 304-311.

7. Bragg, S. M. (2006). Outsourcing: A guide to... Selecting the correct business unit... Negotiating the contract... Maintaining control of the process. John Wiley \& Sons.

8. Burkholder, N. C. (2006). Outsourcing: The definitive view, applications, and implications. John Wiley \& Sons. 
9. Butler, M. G., \& Callahan, C. M. (2014). Human resource outsourcing: Market and operating performance effects of administrative HR functions. Journal of Business Research, 67(2), 218-224.

10. Chen, M.J. (2008). Reconceptualizing the competitioncooperation relationship: a transparadox perspective. Journal of Management Inquiry 17 (4), 288-305.

11. Coase, Ronald H. (1970). The theory of public utility pricing and its application. The Bell Journal of Economics and Management Science, 113-128.

12. Domberger, S., Fernandez, P., \& Fiebig, D. G. (2000). Modelling the price, performance and contract characteristics of IT outsourcing. Journal of Information Technology, 15(2), 107-118.

13. Dwyer, F. R., \& Oh, S. (1988). A transaction cost perspective on vertical contractual structure and interchannel competitive strategies. The Journal of Marketing, 21-34.

14. Dyer, L. M., \& Ross, C. A. (2008). Seeking advice in a dynamic and complex business environment: Impact on the success of small firms. Journal of Developmental Entrepreneurship, 13(02), 133-149.

15. Espino-Rodríguez, T. F., \& Padrón-Robaina, V. (2006). A review of outsourcing from the resource-based view of the firm. International journal of management reviews, 8(1), 49-70.

16. Everaert, P., Sarens, G., \& Rommel, J. (2010). Using Transaction Cost Economics to explain outsourcing of accounting. Small Bus Econ, 35(1), 93-112.

17. Gooderham, P. N., Tobiassen, A., Døving, E., \& Nordhaug, O. (2004). Accountants as sources of business advice for small firms. International small business journal, 22(1), 5-22.

18. Gunasekaran, A., Irani, Z., Choy, K. L., Filippi, L., \& Papadopoulos, T. (2015). Performance measures and metrics in outsourcing decisions: A review for research and applications. International Journal of Production Economics, 161, 153-166.

19. Hennart, J. F. (1989). Can the "new forms of investment" substitute for the "old forms?" A transaction costs perspective. Journal of International Business Studies, 20(2), 211234.

20. Ilić, D., \& Marković, B. (2016). Analysis of the usage of social networks in business, Ekonomski pogledi, 18(3), 53-67 
21. Iqbal, Z., \& Dad, A. M. (2013). Outsourcing: A review of trends, winners \& losers and future directions. International Journal of Business and Social Science, 4(8).

22. Ismail, N. A. (2002). A framework for the study of accounting information systems in small businesses. Akauntan Nasional, 15(5), 32-33.

23. Jayabalan, J., Raman, M., Dorasamy, M., \& Ching, N. K. C. (2009). Outsourcing of Accounting Functions amongst SME Companies in Malaysia: An Exploratory Study. Accountancy Business and the Public Interest, 8(2), 96-114.

24. Kakabadse, A., \& Kakabadse, N. (2002). Trends in outsourcing: Contrasting USA and Europe. European management journal, 20(2), 189-198.

25. Kamyabi, Y., \& Devi, S. (2011d). Using Transaction Cost Economics and Resource-Based views in Management Accounting Outsourcing: An empirical study of Iranian SMEs. Middle East Journal of Scientific Research, 10(1), 87-98.

26. Kang, M., Wu, X., Hong, P., \& Park, Y. (2012). Aligning organizational control practices with competitive outsourcing performance. Journal of Business Research, 65(8), 1195-1201.

27. Klein, P. G. (2005). The make-or-buy decision: Lessons from empirical studies. In Handbook of new institutional economics (pp. 435-464). Springer, Boston, MA.

28. Lai, F., Tian, Y., \& Hou, B. (2012). Relational governance and opportunism in logistics outsourcing relationships: empirical evidence from China. International Journal of Production Research, 50(9), 2501-2514

29. Lindberg, D. L., \& Seifert, D. L. (2010). A New Paradigm of Reporting on the Horizon: International Financial Reporting Standards (IFRS) and Implications for the Insurance Industry. Journal of Insurance Regulation, 29(2)..

30. Marriott, N., \& Marriott, P. (2000). Professional accountants and the development of a management accounting service for the small firm: barriers and possibilities. Management accounting research, 11(4), 475-492.

31. Marttonen, S., \& Kärri, T. (2012). A conceptual model for assessing the profitability of a maintenance outsourcing decision. In: Proceedings of the 17th International Working Seminar on Production Economics.

32. McIvor, R. (2009). How the transaction cost and resource-based theories of the firm inform outsourcing evaluation. Journal of operations management, 27(1), 45-63. 
33. Mohiuddin, M., \& Su, Z. (2013). Offshore outsourcing of core and non-core activities and integrated firm-level performance: An empirical analysis of Québec manufacturing SMEs. Mana gement, 16(4), 454-478.

34. Penrose, E. T. (1959). The theory of the growth ofthe firm. New York: Sharpe.

35. Perunović, Z., Christoffersen, M., \& Mefford, R. N. (2012). Deployment of vendor capabilities and competences throughout the outsourcing process. International Journal of Operations \& Production Management, 32(3), 351-374.

36. Plenert, G. (1993). Optimizing theory of constraints when multiple constrained resources exist. European Journal of Operational Research, 70(1), 126-133.

37. Prahalad, C. K., \& Hamel, G. (2006). The core competence of the corporation. In Strategische unternehmungsplanung - strategische unternehmungsführung (pp. 275-292). Springer, Berlin, Heidelberg.

38. Seddon, P., Cullen, S., \& Willcocks, L. (2002). Does Dombergers Theory of the Contracting Organization Explain Satisfaction with IT Outsourcing?. ICIS 2002 Proceedings, 55.

39. Soberman, D., \& Gatignon, H. (2005). Research issues at the boundary of competitive dynamics and market evolution. Marketing Science, 24(1), 165-174.

40. Stevanović M., Đurđević D. (2017) Offshoring as potential financial instrument in international relations, Ekonomski pogledi, 19(1), 81-97

41. Strambach, S. (2008). Knowledge-Intensive Business Services (KIBS) as drivers of multilevel knowledge dynamics. International journal of services technology and management, 10(2-4), 152-174.

42. Walker, G., \& Weber, D. (1984). A transaction cost approach to make-or-buy decisions. Administrative science quarterly, 373391.

43. Wernerfelt, B. (1984). A Resource-based View of the Firm, Strategic Management Journal, 5(2), 171-180

44. Westphal, P., \& Sohal, A. S. (2013). Taxonomy of outsourcing decision models. Production Planning \& Control, 24(4-5), 347358.

45. Ya Ni, A., \& Bretschneider, S. (2007). The Decision to Contract Out: A Study of Contracting for E-Government Services in State Governments. Public Administration Review, 67(3), 531-544. 
46. Zailani, S., Shaharudin, M. R., Razmi, K., \& Iranmanesh, M. (2017). Influential factors and performance of logistics outsourcing practices: an evidence of Malaysian companies. Review of Managerial Science, 11(1), 53-93.

Рад је примљен: 25.06.2018. Коригована верзија рада је примљена: 19.11.2018. Рад је прихваћен за штампу: 21.11.2018. 